\title{
GAMBARAN PENGGUNAAN ALAT PERLINDUNGAN DIRI SEBAGAI UNIVERSAL PRECAUTION DI INSTALASI RAWAT INAP RSUD WATES KULONPROGO
}

\author{
Anggih Shulchan Yoga Kusuma, Abdul Majid, dan Surantono \\ Jurusan Keperawatan Poltekkes Kemenkes Yogyakarta, \\ shulchanyoga@gmail.com \\ habibiefajar@yahoo.co.id \\ no_ranto@ymail.com
}

\begin{abstract}
Abstrak
Kewaspadaan standar merupakan hal penting mengingat banyaknya kasus penyakit menular. Salah satu aspek dari universal precaution adalah penggunaan alat pelindung diri yang menjadi tujuan penelitian ini. Penelitian deskriptif dengan desain penelitian berupa penelitian survei. Lokasi penelitian di Rumah Sakit Umum Daerah Wates Kulonprogo. Subyek penelitian adalah 57 perawat yang bertugas di Instalasi Rawat Inap RSUD Wates Kulonprogo yang diambil menggunakan metode proportional sampling. Analisis data dilakukan dengan distribusi frekuensi dan prosentase yang mengkategorikan gambaran penggunaan alat pelindung diri di RSUD Wates. Hasil penelitian menunjukkan penggunaan alat pelindung diri di Instalasi Rawat Inap RSUD Wates sebagian besar $(58 \%)$ berada pada kategori baik. Beberapa faktor yang memengaruhi antara lain ketersediaan, motivasi, kepemimpinan, umur, dan imbalan. Peneliti merekomendasikan kepada kepala ruang untuk melakukan monitoring penggunaan alat pelindung diri setiap hari kepada perawat dengan bantuan kartu kendali.
\end{abstract}

Kata kunci: alat pelindung diri, APD, universal precaution, perawat

\section{Abstract}

Universal precaution is important in remembered a lot of disease which is dangerous such as HIV/AIDS and Hepatitis B viruse. One of universal precaution's branch is using personal protective equipment (PPE) which is being the object of the research. Desciptive research with a survey research study design, located in Wates Hospital, Kulonprogo. The Subjects were 57 nurses employeed on Hospitalization Service of Wates Hospital who's gotten by proportional sampling method. Data analysis was conducted by distribute the frequences and percents which categorizing the use of Personal Protective Equipment (PPE). The result is the use of The Personal Protective Equipment (PPE) on Hospitalization Service in Wates Hospital, Kulonprogo by most of nurse (58\%) are in quite well category. Many factors influenced it, such as stock of PPE, motivation, leadership, age, and reward. The recomendation is the head of hospitalizations shoulde be more intensively monitoring the member (nurses) in using PPE by checklist sheet.

Keywords: nurses, personal protective equipment, PPE, universal precaution

\section{Pendahuluan}

Rumah sakit merupakan institusi pelayanan kesehatan yang menyelenggarakan pelayanan kesehatan perorangan secara paripurna dimana menyediakan pelayanan rawat inap, rawat jalan, dan rawat darurat, (UU RI No. 44 Tahun 2009 tentang Rumah Sakit). Tenaga keperawatan memiliki andil yang besar dalam pelayanan rumah sakit dengan populasi mencapai $60 \%$ dari tenaga kesehatan yang lain (PPNI, 2014) ${ }^{2}$. Pengkajian (assesment) dapat dilakukan oleh dokter atau perawat (UU RI, 24/2009 \& UU RI No 38/2014). Pengkajian yang dilaksanakan membutuhkan teknik agar tenaga medis yang mengkaji tersebut tidak tertular. Dengan dasar tersebut, maka ditetapkan suatu peraturan agar petugas kesehatan tidak tertular penyakit yang diderita oleh klien, yakni penerapan 
kewaspadaan standar (universal precaution) terhadap setiap klien yang datang ke rumah sakit. Kewaspadaan standar ini menjadi penting mengingat banyaknya kasus penyakit menular pada era sekarang ini, diantaranya yang berbahaya adalah HIV/AIDS dan Hepatitis B (WHO, 2013).

Kabupaten Kulonprogo menempati urutan ketiga tertinggi penderita HIV/AIDS di DIY setalah Kota Yogyakarta dan Kabupaten Bantul, dengan jumlah penderita HIV sebanyak 72 orang dan AIDS sebanyak 51 orang $^{6}$. Pada penyakit Hepatitis B, 2 miliar penduduk dunia telah terinfeksi virus Hepatitis B, dengan 400 juta diantaranya menderita Hepatitis B kronis ${ }^{7}$. Diperkirakan akan ada 10-30 juta orang terinfeksi setiap tahunnya. Di Indonesia, kasus Hepatitis B mengalami peningkatan. Sebanyak 1,2\% atau 2.981.075 jiwa penduduk Indonesia terinfeksi Hepatitis. Dari jumlah tersebut, 21,8\% atau sekitar 649.875 jiwa terindikasi Hepatitis $B^{8}$. Daerah Istimewa Yogyakarta memiliki prevalensi $0,9 \%$ pada tahun 2013, dengan proporsi hepatitis B pada angka 15,5. Berikut Trend Penyakit HIV/AIDS, Hepatitis B, dan TBC Instalasi Rawat Inap RSUD Wates Tahun 2012 sampai 2014 yang ditampilkan dalam diagram.

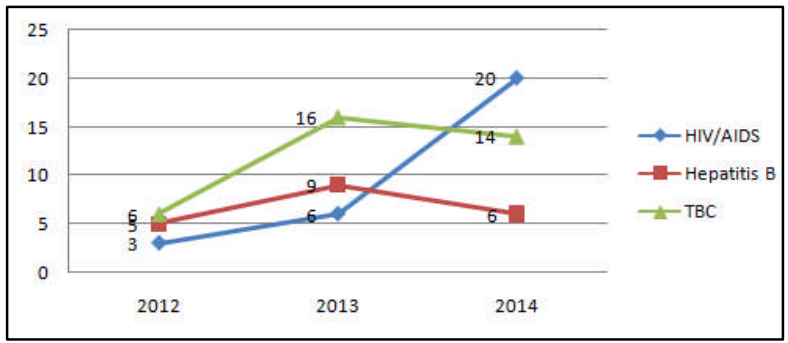

Melihat data tersebut, tentunya mendorong petugas medis untuk waspada terhadap segala penyakit, terlebih pada penyakit HIV/AIDS dan Hepatitis B; ditunjang dengan Keputusan Menteri Kesehatan RI Nomor 270/Menkes/SK/III/2007 tentang "Pedoman Manajerial Pencegahan dan Pengendalian Infeksi di Rumah Sakit dan Fasilitas Pelayanan Kesehatan Lainnya" yang berbunyi "Semua rumah sakit dan fasilitas pelayanan kesehatan lainnya harus melaksanakan pencegahan dan pengendalian infeksi (PPI)".

Penelitian tentang penerapan alat perlindungan diri di RSUD Wates pernah dilakukan oleh Wibawanti (2013). Hasil penelitian yang dilaksanakan di Instalasi Bedah Sentral menunjukkan bahwa semua perawat yang berjumlah 7 orang patuh terhadap penggunaan sarung tangan, masker, penutup kepala, gaun bedah, jas bedah, dan alas kaki. Namun, tingkat kepatuhan untuk pemakaian kaca mata sebesar 57,11\% dan apron sebesar 95,24\% ${ }^{9}$.

Pemakaian sarung tangan merupakan prosedur wajib dalam melakukan tindakan invasif. Studi awal yang dilakukan kepada Kepala Ruang Wijaya Kusuma melalui wawancara juga didapatkan bahwa pelindung diri yang digunakan hanyalah masker dan sarung tangan nonsteril. Protokol pemakaian alat pelindung diri yang diterapkan di ruangan pada waktu itu adalah menggunakan masker dan sarung tangan nonsteril ganda. Tujuan Penelitian Memperoleh gambaran tentang penerapan Alat Perlindungan Diri (APD) di Instalasi Rawat Inap RSUD Wates Kulonprogo.

\section{Metode Penelitian}

Penelitian ini dilakukan dilakukan di Instalasi Rawat Inap RSUD Wates Kulonprogo pada tanggal 15 Maret 2015 sampai dengan 20 April 2015. Desain penelitian yang digunakan dalam penelitian ini adalah penelitian survey ${ }^{10}$. Populasi yang digunakan dalam proses penelitian ini adalah semua perawat yang bekerja di Instalasi Rawat Inap RSUD Wates Kulonprogo yang berjumlah 130 orang yang diambil dari Ruang Anggrek, Bougenville, Cempaka, Dahlia, Edelweiss, Flamboyan, Gardenia, Melati, dan Wijaya Kusuma. Teknik pengambilan sampel dalam penelitian ini menggunakan proportional sampling dengan 
penghitungan jumlah sampel menggunakan persamaan rumus Slovin sebagai berikut ${ }^{10}$. Melalui persamaan tersebut serta dengan standar deviasi $(d)=0,1$ maka didapatkan hasil jumlah sampel sebesar 57 responden.

Kriteria responden dalam penelitian ini meliputi kriteria inklusi dan ekslusi. Kriteria inklusi dalam pelelitian ini adalah perawat RSUD Wates yang berdinas di Instalasi Rawat Inap, bersedia dilakukan obserbvasi, pada saat penelitian berada pada tempat penelitian, merupakan Pegawai Negeri Sipil (PNS) atau Calon PNS, dan pendidikan minimal DIII Keperawatan. Sedangkan kriteria ekslusi dalam penelitian ini adalah perawat yang menolak dilakukan observasi, tidak sedang berada di tempat penelitian, dan berstatus sebagai perawat diklat (training).

Instrumen pengumpul data yang digunakan dalam proses pengumpulan data penelitian ini adalah pengukuran observasi ${ }^{11}$. Observasi dilakukan pada perawat yang melakukan kegiatan invasif meliputi pemasangan infus, perawatan luka, menolong buang air kecil/buang air besar, pemasangan NGT, dan injeksi obat yang membutuhkan penggunaan APD 6 . Penelitian menggunakan enam lembar observasi yang meliputi lembar observasi ketersediaan APD yang ada di ruangan, lembar observasi checklist penggunaan seluruh APD (masker, sarung tangan steril/nonsteril, apron/jas pelindung, dan pelindung kaki), lembar observasi penggunaan masker, lembar observasi penggunaan sarung tangan, lembar observasi penggunaan apron/jas pelindung, dan lembar observasi penggunaan pelindung kaki. Seluruh lembar observasi dilakukan uji pemahaman kepada Kepala Bidang Keperawatan RSUD Wates dan didapatkan hasil tidak ada penambahan isi maupun susunan lembar observasi. Data dikategorikan menjadi kategori baik (76-100\% penggunaan APD), cukup (56-75\% penggunaaan APD), dan kurang (<55\% penggunaan APD $)^{12}$.

\section{Hasil}

Karakteristik responden didapatkan dari 57 perawat di Instalasi Rawat Inap RSUD Wates yang masuk dalam kriteria inklusi. Detil karakteristik responden dapat dilihat pada Tabel 1.

Tabel 1. Distribusi Responden di Instalasi Rawat Inap RSUD Wates

\begin{tabular}{lcc}
\hline \multicolumn{1}{c}{ Karakteristik } & Frekuensi & Prosentase \\
\hline Janis Kelamin & & \\
a. Laki-laki & 51 & 89 \\
b. Perempuan & 6 & 11 \\
\hline Usia & 24 & 42 \\
a. 15 - 30 tahun & 31 & 56 \\
b. 31 - 45 tahun & 1 & 2 \\
c. 46-60 tahun & & \\
\hline Pendidikan & 52 & 91 \\
a. DIII & 5 & 9 \\
b. S-1 & 50 & 88 \\
\hline Jabatan fungsional & 7 & 12 \\
a. Perawat Primer & & \\
b. Perawat Pelaksana & 42 & 9 \\
\hline Kelas Perawatan & 10 & 18 \\
a. Kelas I & 5 & 74 \\
b. Kelas II & & \\
c. Kelas III & &
\end{tabular}

Hasil observasi tentang ketersediaan APD di masing masing ruangan diketahui bahwa semua ruang rawat inap yang meliputi Ruang Anggrek, Ruang Bougenville, Ruang Cempaka, Ruang Dahlia, Ruang Edelweiss, Ruang Flamboyan, Ruang Melati, dan Ruang Wijaya 
Kusuma menyediakan alat pelindung diri masker, sarung tangan steril, sarung tangan nonsteril, apron, jas pelindung, dan pelindung kaki (sepatu boot). Alat pelindung diri tersebut disediakan oleh rumah sakit atas dasar Surat Keputusan Direktur RSUD Wates No 188/77.3/5/I/2011 tentang Pencegahan dan Pengendalian Infeksi di RSUD Wates.

Penggunaan APD pada perawat Instalasi Rawat Inap RSUD Wates.

Tabel 2. Distribusi Penggunaan Alat Pelindung Diri

di Instalasi Rawat Inap RSUD Wates

\begin{tabular}{ccc}
\hline $\begin{array}{c}\text { Penggunaan APD di } \\
\text { Instalasi Rawat Inap }\end{array}$ & Frekuensi & Prosentase \\
\hline Baik & 33 & 58 \\
Cukup & 21 & 37 \\
Kurang & 3 & 5 \\
\hline Jumlah & 57 & 100 \\
\hline
\end{tabular}

Penggunaan Alat Pelindung Diri pada perawat di Instalasi Rawat Inap RSUD Wates sebanyak $58 \%$ berada pada kategori baik,

Tabel 3. Distribusi Tingkat Penggunaan APD Masker Instalasi Rawat Inap RSUD Wates

\begin{tabular}{ccc}
\hline Pengggunaan APD Masker & Frekuensi & Prosentase \\
\hline Baik & 51 & 89 \\
Cukup & 2 & 4 \\
Kurang & 4 & 7 \\
\hline Jumlah & 57 & 100 \\
\hline
\end{tabular}

Observasi dilakukan dengan mengamati penggunaan masker yang sesuai indikasi di SOP dan pelaksanaan yang memenuhi standar SOP meliputi: cuci tangan sebelum dan sesudah memakai masker, pemastian fiksasi dan keutuhan masker, serta penanganan kontaminasi setelah masker dipakai. Dari observasi tersebut, didapatkan hasil sebagian besar perawat $(89 \%)$ berada pada kategori baik untuk penggunaan APD masker.

Tabel 4. Distribusi Tingkat Penggunaan APD Sarung tangan Instalasi Rawat Inap RSUD Wates

\begin{tabular}{lcc}
\hline \multicolumn{1}{c}{ Penggunaan APD } & Frekuensi & Prosentase \\
Sarung Tangan & & \\
\hline Baik & 49 & 86 \\
Kurang & 8 & 14 \\
\hline Jumlah & 57 & 100 \\
\hline
\end{tabular}

Observasi dilakukan dengan mengamati penggunaan sarung tangan yang sesuai indikasi di SOP dan pelaksanaan yang memenuhi standar SOP meliputi: cuci tangan sebelum dan sesudah memakai sarung tangan, pemastian fiksasi dan keutuhan sarung tangan, prinsip bersih/steril sarung tangan, serta penanganan kontaminasi setelah sarung tangan dipakai yang kesemuanya dinilai melalui 15 checklist pernyataan. Hasil penelitian menunjukkan bahwa sebagian besar perawat (86\%) berada pada kategori baik untuk penggunaan APD sarung tangan.

Observasi dilakukan dengan mengamati penggunaan apron yang sesuai indikasi di SOP dan pelaksanaan yang memenuhi standar SOP meliputi: cuci tangan sebelum dan sesudah memakai apron, pemastian fiksasi apron, serta penanganan kontaminasi apron dipakai yang kesemuanya dinilai melalui 11 checlkist pernyataan. Penelitian penggunaan apron sebagai pelindung tubuh dilakukan juga pada perawat yang memakai jas pelindung yang terbuat dari 
kain. Penelitian ini dilakukan atas dasar persamaan fungsi apron dan jas pelindung yang sama-sama melindungi bagian tubuh bagian depan dari cipratan cairan/darah pasien agar tidak mengenai perawat.

Penelitian penggunaan apron/jas pelindung dilakukan hanya pada perawat yang akan melakukan tindakan dengan indikasi harus memakai apron/jas pelindung, seperti menolong pasien buang air kecil atau buang air besar dan melakukan perawatan luka besar. Perawat yang dapat dilakukan observasi berjumlah 18 perawat dan didapatkan hasil bahwa semua perawat yang menjadi subjek penelitian (18 perawat) berada pada kategori baik (100\%) untuk penggunaan APD apron/jas pelindung.

Observasi dilakukan dengan mengamati penggunaan pelindung kaki yang sesuai indikasi di SOP dan pelaksanaan yang memenuhi standar SOP meliputi: cuci tangan sebelum dan sesudah memakai pelindung kaki, pemastian fiksasi dan kenyamanan pelindung kaki, serta prinsip tahan benda tajam dan cairan kimia berbahaya yang kesemuanya dinilai melalui 9 checlkist pernyataan. Pelindung kaki yang dimaksud peneliti adalah pelindung kaki yang terbuat dari kulit atau karet tahan cairan kimia dan benda tajam, seperti sepatu kulit dan sepatu boot. Sepatu kulit dapat dianggap sebagai pelindung kaki dikarenakan sifat kulit yang dapat menahan masuknya cairan ke dalam sepatu serta tahan terhadap jatuhnya benda tajam seperti jarum suntik. Sepatu kulit juga dianggap sebagai pelindung kaki atas anjuran dari Direktur RSUD Wates terkait seragam dinas yang sekaligus dapat melindungi perawat.

Tabel 5. Distribusi Tingkat Penggunaan APD Pelindung Kaki Instalasi Rawat Inap RSUD Wates

\begin{tabular}{ccc}
\hline $\begin{array}{c}\text { Penggunaan APD } \\
\text { Pelindung Kaki }\end{array}$ & Frekuensi & Prosentase \\
\hline Baik & 39 & 68 \\
Kurang & 18 & 32 \\
\hline Jumlah & 57 & 100 \\
\hline
\end{tabular}

Hasil penelitian menunjukkan bahwa sebagian besar perawat $(68 \%)$ berada pada kategori baik untuk penggunaan APD pelindung kaki.

\section{Pembahasan}

Berdasarkan hasil penelitian, diketahui bahwa seluruh ruang (9 ruang) di Instalasi Rawat Inap RSUD Wates $(100 \%)$ menyediakan alat pelindung diri yang meliputi masker, sarung tangan steril, sarung tangan nonsteril, apron, dan pelindung kaki. Semua jenis alat pelindung diri tersebut disediakan di masing-masing ruang yang ditempatkan di ruang tindakan agar perawat mudah dalam mengambil dan menggunakan. Penyediaan alat pelindung tersebut diselenggarakan oleh rumah sakit dengan biaya yang bersumber dari dana jaminan kesehatan (BPJS, Jamkesda, Jaminan khusus). Penyediaan alat pelindung tersebut diatur dalam Surat Keputusan Direktur RSUD Wates No 188/77.3/5/I/2011 tentang Pencegahan dan Pengendalian Infeksi di RSUD Wates.

Penyediaan alat pelindung diri di RSUD Wates ini sesuai dengan Teori yang menyatakan bahwa sarana merupakan elemen dari input. Keberadaaan sumber daya dalam suatu organisasi merupakan hal yang paling pokok sekaligus sebagai dasar untuk berfungsi suatu organisasi. Ada atau tidaknya sumberdaya seperti uang, waktu, dan peralatan yang dialokasikan oleh organisasi akan berpengaruh pada kinerja. RSUD Wates telah melakukan salah satu upaya dalam menjalankan fungsi organisasi yakni dengan menyediakan alat pelindung diri secara kontinyu agar tujuan rumah sakit menerapkan universal precaution dalam rangka mencegah infeksi silang tercapai, (Robbins, dan Judge, 2007).

Pada faktor pendidikan, perawat dengan jenjang pendidikan Diploma III lebih banyak tidak memenuhi penggunaan APD secara baik dibanding dengan perawat dengan pendidikan 
S1. Hal tersebut dikarenakan kemampuan intelektual seseorang akan berpengaruh pada kegiatan yang membutuhkan kekuatan intelektual dan keterampilan (Robbins, dan Judge, 2007). Faktor jabatan juga berkemungkinan mempengaruhi penggunaan APD. Jabatan berpengaruh pada imbalan atau gaji yang berfungsi untuk memotivasi staf untuk mencapai prestasi yang tinggi (Gibson, 2008). Faktor terakhir yang menjadi pemungkin terdapatnya 24 perawat yang berada pada kategori cukup dan kurang adalah faktor tempat pelayanan. Perawat dengan tempat kerja kelas yang lebih tinggi cenderung lebih baik dalam menggunakan APD. Hal ini sesuai dengan fungsi imbalan untuk mempertahankan staf bekerja dan mencapai prestasi yang sebaik-baiknya (Gibson, 2008).

Berdasarkan aspek-aspek yang diteliti pada APD masker, diketahui bahwa penggunaan masker di Instalasi Rawat Inap RSUD Wates tergolong baik. Hal tersebut dilihat dari prinsip cuci tangan sebelum dan sesudah penggunaan masker, pemakaian masker sendiri yang telah dipaskan sehingga menutup hidung dan mulut, serta kontrol pemakaian masker yang tidak boleh sampai sobek, berlubang, maupun basah. Prinsip dekontaminasi yang masih perlu diperhatikan adalah terkait dengan pengalungan masker di leher sebelum dibuang. Pengalungan masker tersebut dapat berdampak pada masuknya agen infeksi yang bersumber dari leher yang tidak tertutup pelindung dan menempel pada bagian dalam masker.

Penggunaan APD Masker yang dilakukan perawat Instalasi Rawat Inap RSUD Wates dapat tergolong baik tidak lepas dari peran serta instansi yang selalu mengingatkan anggotanya untuk menjaga diri dari penularan silang penyakit. Kepala ruang di akhir sesi preconference selalu mengingatkan kepada anggotanya agar selalu bekerja secara disiplin. Hal ini sesuai dengan teori yang dikemukakan oleh Pramono (2013) bahwa pemimpin mempunyai tanggungjawab memberdayakan anggotanya untuk mencapai tujuan bersama.

Berdasarkan aspek-aspek yang diteliti pada APD sarung tangan, diketahui bahwa penggunaan sarung tangan sudah sesuai dengan prinsip hygiene dan fungsi sarung tangan. Perawat sudah melakukan cuci tangan sebelum dan sesudah memakai sarung tangan. Sarung tangan yang dipakai sudah sesuai dengan jenis yang dianjurkan oleh Departemen Kesehatan dan Panduan rumah sakit. Serta limbah sarung tangan yang telah dipakai juga ditempatkan di tempat sampah medis. Terkait dengan pelaksanaan pemakaian sarung tangan, pada aspek fiksasi dan keutuhan sarung tangan telah dilakukan dengan baik. Namun pada aspek hygiene sebagai universal precaution, penggunaan sarung tangan masih pada banyak pasien dan tindakan sekaligus tanpa penggantian sarung tangan. Hal ini dapat meningkatkan risiko infeksi nosokomial dari pasien satu ke pasien yang lain (Depkes RI, 2008). Padahal fungsi sarung tangan pada petugas adalah sebagai salah satu elemen universal precaution, (WHO, 2008). ${ }^{16}$. Sehingga, dapat diketahui bahwa penerapan universal precaution pada aspek sarung tangan di Instalasi Rawat Inap baik pada sisi perawat, namun kurang menguntungkan di sisi pasien dan lingkungan, (Depkes RI, 2008).

Pelaksanaan penggunaan alat pelindung diri ini dipengaruhi oleh beberapa hal. Terkait dengan kepatuhan penggunaan APD sarung tangan, faktor ketersediaan alat menjadi faktor pertama $^{13}$. Setiap ruang menyediakan alat pelindung diri sarung tangan, baik tipe steril maupun nonsteril. Sesuai dengan pengamatan peneliti, perawat tinggal mengambil sarung tangan di ruang tindakan sesuai dengan tipe dan setelah itu memakainya. Faktor yang kedua yakni kepemimpinan (Pramono, 2013). Kepala ruang selalu mengingatkan anggota perawat untuk selalu menerapkan tindakan sesuai dengan Standar Operasional Prosedur. Sesama teman perawat pun mengingatkan ketika ada perawat yang sedang bersama tidak menggunakan sarung tangan saat akan melakukan tindakan invasif.

Faktor ketiga adalah kebijakan Rumah Sakit (Depkes RI, 2008). Kebijakan tersebut adalah agar tenaga kesehatan melakukan penghematan alat kesehatan habis pakai. Hal ini disampaikan salah satu perawat bahwa perawat harus menghemat alat-alat yang dibebankan kepada pasien agar cost yang ditanggung tidak melebihi beban. Penghematan tersebut tentu 
baik dilakukan, tetapi persepsi dari perawat yang menganggap hemat adalah memakai sedikit mungkin dengan mengesampingkan prinsip utama pemakaian APD tersebut merupakan hal yang harus diluruskan ${ }^{6}$. Kepala ruang perlu lebih menekankan pentingnya keselamatan pasien dengan memakai APD sesuai dengan kuantitas yang dibutuhkan (Pramono, 2013).

Pelaksanaan observasi penggunaan apron/jas pelindung tidak dapat dilakukan pada seluruh responden (57 responden) dikarenakan tindakan dengan indikasi penggunaan apron/jas pelindung terbatas. Selain itu, apron yang dipakai perawat adalah jas pelindung yang terbuat dari kain tebal yang dapat menahan cairan kontaminan secara langsung ke baju perawat. Sedikitnya pemakai jas pelindung juga dipengaruhi oleh kebiasaan di ruang tempat perawat tersebut praktik ${ }^{15}$. Ruang kelas I dan II membiasakan perawat memakai jas pelindung agar lebih melindungi perawat dan menambah estetika dari perawat yang bertugas. Menurut penuturan dari perawat di ruang kelas III yang dulunya bertugas di ruang rawat kelas I, dirinya tetap memakai jas pelindung dengan alasan agar lebih terlindung dari patogen yang ada di lingkungan pasien. Perlindungan atas kesadaran diri tersebut sesuai dengan teori yang dikemukakan oleh Gibson (2008) bahwa motivasi merupakan konsep yang digunakan untuk menggambarkan dorongan yang timbul di dalam seorang individu yang menggerakkan dan mengarahkan perilaku.

Terkait dengan fungsi apron sebagai alat pelindung diri dari cairan kontaminan yang oleh perawat dalam keseharian diganti dengan penggunaan jas pelindung kain, menurut standar dari Depkes dalam Pedoman Pencegahan dan Pengendalian Infeksi di Rumah Sakit, hal itu belumlah sesuai. Kain memiliki pori-pori yang lebih besar daripada plastik pada apron. Ketika kain terkena cairan, makan cairan akan menembes masuk. Pada kasus yang mengalami pemancuran cairan yang banyak seperti pada saat pertolongan buang air kecil, cairan yang mengenai jas pelindung akan teresap masuk ke pakaian perawat. Ketika kulit perawat tidak utuh atau terjadi luka, bakteri/virus pada urin akan masuk ke perawat. Ketika bakteri/virus memiliki virulensi yang tinggi dan perawat dalam keadaan tidak fit, makan perawat dapat tertular penyakit pasien tersebut (Depkes RI, 2008).

Pelindung kaki yang digunakan oleh perawat di Instalasi rawat inap meliputi pelindung kaki yang terbuat dari karet berbentuk sepatu boot, serta pelindung kaki berbentuk sepatu dinas yang terbuat dari kulit. Peneliti memasukkan sepatu dinas yang terbuat dari kulit dikarenakan memenuhi unsur dan prinsip fungsi pelindung kaki, yakni tahan terhadap benda tajam (jarum dan kaca) serta tahan terhadap rembesan cairan (darah, obat, dan urin). Namun, tidak semua sepatu dinas dikategorikan sebagai pelindung kaki. Selain tahan terhadap benda tajam dan cairan, sepatu juga harus menutup punggung kaki sampai mata kaki. Hal ini karena punggung kaki memiliki luas penampang paling lebar ketika suatu benda terjatuh (Depkes RI, 2008).

Pada perawat yang memakai sepatu namun sepatu yang digunakan tidak memenuhi syarat di atas, maka peneliti kategorikan perawat tersebut tidak memakai pelindung kaki. 18 perawat yang terkategorikan tidak memakai pelindung kaki rata-rata memakai sepatu yang hanya menutup sampai atas jari kaki serta tidak terbuat dari karet melainkan kain keras tidak tahan cairan. Selain itu, pada perawat yang dinas sore, rata-rata menggunakan sandal pada saat melakukan tindakan. Ketika diwawancara, perawat mengatakan bahwa tidak nyaman memakai sepatu terus menerus serta sedang tidak ada pengawasan dari atasan atau supervisi. Keadaan seperti ini sesuai dengan teori Pramono (2013) yang menyatakan bahwa pemimpin mempunyai pengaruh terhadap anggotanya.

\section{Kesimpulan}

Hasil penelitian menunjukkan penggunaan alat pelindung diri di Instalasi Rawat Inap RSUD Wates berada pada kategori baik. Rumah Sakit telah melakukan salah satu upaya dalam menjalankan fungsi organisasi yakni dengan menyediakan alat pelindung diri secara 
kontinyu agar tujuan rumah sakit menerapkan universal precaution dalam rangka mencegah infeksi.

\section{Daftar Pustaka}

Depkes RI. (2008). Pedoman Pencegahan dan Pengendalian Infeksi di Rumah Sakit dan Fasilitas Pelayanan Kesehatan Lainnya. Jakarta: Departemen Kesehatan RI.

Depkes RI. (2013). Riset Kesehatan Dasar Tahun 2013. Jakarta: Depkes RI.

Gibson. (2008). Manajemen Sumber Daya Manusia: Edisi Keempat. Jakarta : Erlangga.

Hepatitis B Foundation. (2014). Hepatitis B Statistics. Diunduh tanggal 3 Januari 2015 dari http://www.hepb.org/ hepb/statistics.

Undang-undang Republik Indonesia No. 44 Tahun 2009 tentang Rumah Sakit

Persatuan Perawat Nasional Indonesia. (2014). Undang-Undang Keperawatan: Perawat Siap Dukung Revolusi Kesehatan. Diunduh pada tanggal 3 Januari 2015 dari http://.innappni.or.id/ index.php /component/content/article/85-berita/142-undangundang-keperawatan-perawat-siap -dukung -revolusi-pelayanan-kesehatan.

Pramono, Octavia. (2013). Leadership 1/2 Malaikat. Yogyakarta: Syura Media Utama.

Robbins, dan Judge. (2007). Perilaku Organisasi, Alih Bahasa Drs. Benyamin Molan. Jakarta: Salemba Empat.

Undang-undang Republik Indonesia No. 29 Tahun 2004 tentang Praktik Kedokteran.

Undang-undang Republik Indonesia No. 38 Tahun 2014 tentang Keperawatan.

Wibawanti, Rina. (2013). Kepatuhan Perawat Dalam Pelaksanaan Protap Penggunaan Alat Perlindungan Diri di Instalasi Bedah Sentral RSUD Wates Kulonprogo. Skripsi: Poltekkes Kemenkes Yogyakarta Jurusan Keperawatan. Yogyakarta: Poltekkes Kemenkes Yogyakarta.

World Health Organization. (2014). Global Health Observatory: HIV/AIDS. Diunduh pada tanggal 31 Desember 2014 dari HIV/AIDS http://www.who.int/ entity/gho/hiv/_status/cases_all/en/index.html

World Health Organization. (2008). Standard Precautions (Bahasa: Penerapan Kewaspadaan Standar di Fasilitas Pelayanan Kesehatan). Switzerland: WHO. 